\title{
Economic and Yield Assessment of Maize Varieties Under Recommended and Double Plant Population Densities
}

\author{
Egbetokun Olugbenga Aderemi*, Oloyede-Kamiyo Quadrah Olaitan \\ Institute of Agricultural Research and Training, Faculty of Agriculture, Obafemi Awolowo University, Moor Plantation, Ibadan, Nigeria
}

\author{
Email address: \\ oaegbetokun@gmail.com (E. O. Aderemi) \\ ${ }^{*}$ Corresponding author
}

\section{To cite this article:}

Egbetokun Olugbenga Aderemi, Oloyede-Kamiyo Quadrah Olaitan. Economic and Yield Assessment of Maize Varieties Under Recommended and Double Plant Population Densities. American Journal of Environmental Science and Engineering.

Vol. 4, No. 3, 2020, pp. 31-35. doi: 10.11648/j.ajese.20200403.11

Received: December 10, 2019; Accepted: June 12, 2020; Published: August 10, 2020

\begin{abstract}
Attempts have been made to increase maize productivity and yield in Nigeria by doubling the recommended population density under the same agronomic practices but with additional $50 \%$ increase in fertilizer application. However, the prevailing wage rates paid to farm labour, the market price of other inputs especially additional fertilizer and output will determine the benefit. The aim of this study was to assess the economic benefits of using double plant population density. Four maize varieties LNTP-W, BR9943-DMRSR, LNTP-Y and BR9928-DMRSR were tested under recommended population density (ND) of 53,333 plants/ha and double plant density (DD) of 106,666 plants/ha at Ilora and Ile-Ife out-stations of the Institute of Agricultural Research and Training (IAR\&T), Nigeria in 2017 and 2018 cropping seasons. Plant spacing of $75 \mathrm{~cm}$ inter-row and $25 \mathrm{~cm}$ intra-row was used for both ND and DD. The experiment was laid out on $3 \mathrm{~m}$ by $3 \mathrm{~m}$ plots in a Randomized Complete Block Design with three replications. Data on cost (input and labour) and yield were collected. The analytical techniques used was partial budgeting analysis which include Gross benefit (GB), Net Benefit (NB) and Benefit-Cost Ratio (BCR). Yield performance result showed that at both locations, LNTP-W performed best under ND and DD followed by BR9943DMRSR. The result of partial budgeting showed that NB of LNTP-W was the highest under ND $(\mathrm{N} 206,146)$ and DD $(\mathrm{N} 152,724)$, followed by BR9943DMRSR $(\mathrm{N} 169,894)$ under ND and $(\mathrm{N} 121,242)$ under DD respectively. However, the BC ratio result showed that BR9943DMRSR maize variety was the most economic viable variety. Therefore, since BR9943DMRSR maize variety satisfied both the necessary and sufficient conditions for economic benefit feasibility for adoption by farmers under both normal and double plant population densities, it is recommended that this maize variety should be adopted by farmers for increased productivity. Also, mass production of this variety is encouraged by the research institute with the support of the government and made available through the extension agents for dissemination and adoption by farmers.
\end{abstract}

Keywords: Population Densities, Partial Budgeting, Maize, Cost and Profitability

\section{Introduction}

New technology can be evaluated in terms of its impact on the productivity, profitability, acceptability and sustainability of farming systems [1]. Before changing from one production method to another, farmers consider many factors, such as agro-ecological requirements, availability of required additional production resources vis a vis labour, credits, skill, farmland, equipment; and additional income resulting from the change [2, 3]. Farmers also consider the compatibility of the new technology with socio-cultural circumstances, goals and the whole farming system. They want to know if the extra income earned by changing to the new technology justify the extra cost [4].

Economic analysis is conducted to assess the feasibility of the treatments using a partial budget, dominance and marginal analysis of each treatment. Partial budget analysis (PBA) provides useful information for making decisions on such a change in technology. Partial budget analysis can be used for comparing the impact of a technological change on farm costs and returns. It also provides the foundation for comparing the relative profitability of alternative treatments, evaluating their riskiness, and testing how robust profits are in the event of changing product or input prices $[5,6]$. The partial budget included the average yields for each treatment, 
the adjusted yields, the gross field benefit and the total costs. The total costs which vary are the sum of all cost for alternative treatments. Partial budget analysis should be employed to estimate the net benefit and marginal rate of return that could be obtained from various alternative treatments $[1,4]$.

Attempts have been made to increase maize productivity and yield in Nigeria by doubling the recommended population density of 53,333 plants/ha under the same agronomic practices but with additional 50\% increase in fertilizer application [7]. This attempt has yielded different results, while some showed increase in yield, some showed decline in yield. However, the yield increase should justify additional input. While the interest is on the performance of maize varieties under double plant density, the prevailing wage rates paid to farm labour, the market price of other inputs especially additional fertilizer and output will determine the benefit $[4,8,9]$. The aim of this study was to assess the economic benefits or otherwise of using double plant population density among four maize varieties.

\section{Materials and Methods}

Four maize varieties were tested under recommended population density (ND) of 53,333 plants/ha and double plant density (DD) of 106,666 plants/ha at Ilora and Ile-Ife out- stations of the Institute of Agricultural Research and Training (IAR\&T), Nigeria in 2017 and 2018 cropping season. However, the trial was carried out in Ile-Ife only in 2017. Ilora is located in the derived savannah $\left(7^{\circ} 48^{\prime} \mathrm{N}\right.$ and $3^{\circ} 54^{\prime}$ E), while Ile-Ife is located in the rain forest zone of Nigeria $\left(7^{\circ} 31^{\prime} \mathrm{N}\right.$ and $\left.4^{\circ} 31^{\prime} \mathrm{E}\right)$. The four maize varieties used were LNTP-W, BR9943-DMRSR, LNTP-Y and BR9928-DMRSR. Similar plant spacing of $75 \mathrm{~cm}$ inter-row and $25 \mathrm{~cm}$ intra-row was used for both ND and DD. However, ND had one plant per hill, while the DD plots had two plants per hill. The experiment was laid out in a Randomized Complete Block Design with three replications. Plot size was $3 \mathrm{~m}$ by $3 \mathrm{~m}$.

Similar agronomic practices were carried out for both population densities, however, DD plots received additional fifty percent of fertilizer. Data were collected on yield and yield parameters. Mean yield under ND and DD was estimated.

The techniques used in the study include Gross benefit (GB), Net Benefit (NB) and Benefit-Cost Ratio (BCR).

\subsection{Gross Benefit}

Gross benefit calculation was done to have an estimate of the difference between the gross return and variable costs. Gross benefit was calculated by using the method as given by $[10,11]$ using the following formula;

Gross benefit $(\mathrm{N} / \mathrm{ha})=$ Gross return $(\mathrm{N} / \mathrm{ha})$ - Total variable cost $(\mathrm{N} / \mathrm{ha})$

\subsection{Net Benefit}

Net Benefit was used to determine the overall positive impact of the treatments in monetary values [12]. NB was calculated in the study as the difference between gross returns (GR) and the total variable cost (TVC). The formula is given as:

$$
\mathrm{NB}(\mathrm{N} / \mathrm{ha})=\mathrm{GB}(\mathrm{N} / \mathrm{ha})-\operatorname{TVC}(\mathrm{N} / \mathrm{ha})
$$

\subsection{Benefit-Cost Ratio (BCR)}

Benefit-cost ratio is the quick and easiest method to determine the economic performance of a business. It is a relative measure, which is used to compare benefit per unit of cost. Benefit-Cost Ratio (BCR) is an indicator, used in the formal discipline of cost-benefit analysis, which attempts to summarize the overall value for money of a project [4]. Undiscounted benefit-cost ratio was estimated as a ratio of gross return and total variable cost. Thus, the benefit-cost (BCR) analysis was carried out by using formula;

$$
B C R=\frac{N B}{T V C}
$$

\section{Results and Discussion}

Yield performance of the maize varieties across locations is presented in Table 1. Generally, at both locations, LNTPW performed best under ND and DD followed by BR9943DMRSR. This was so due to the yield potential of each maize variety. Yield under DD was a bit lower than under ND except in few instances. For instance, grain yield under DD was higher than under ND for BR9943DMRSR at Ile-Ife and for BR9928DMRSR at Ilora. Working on population density of 69,136 to 106,173 plants ha-1, it was also reported that varying maize hybrids, plant population, and row configuration had inconsistent effects on grain yield, yield components, plant morphology and leaf area, interception of solar radiation, and stalk lodging [13]. A study report on hybrids showed that increase in yield results from the ability of the newest hybrids to continue to produce an ear on every plant [14]. Furthermore, [15] working on sorghum reported that plant densities of 83,500 and 93,750 plants/ha gave the highest grain yield compared with population density 62,500 plants/ha.

\begin{tabular}{|c|c|c|c|c|c|c|}
\hline \multirow{2}{*}{ Variety } & \multicolumn{3}{|l|}{ ND } & \multicolumn{3}{|l|}{ DD } \\
\hline & Ile-Ife & Ilora & Mean & Ile-Ife & Ilora & Mean \\
\hline LNTP-W & 5.26 & 2.73 & 3.99 & 5.18 & 2.43 & 3.81 \\
\hline LNTP-Y & 4.25 & 2.34 & 3.29 & 2.35 & 1.64 & 1.99 \\
\hline BR9928DMRSR & 3.05 & 2.09 & 2.57 & 2.51 & 2.47 & 2.49 \\
\hline
\end{tabular}

Table 1. Yield (tons/ha) performance of the varieties under varied densities at Ilora and Ile-Ife in 2017 and 2018. 


\begin{tabular}{lllllll}
\hline \multirow{2}{*}{ Variety } & ND & \multicolumn{7}{c}{ DD } \\
\cline { 2 - 7 } & Ile-Ife & Ilora & Mean & Ile-Ife & Ilora & Mean \\
\hline BR9943DMRSR & 4.61 & 2.61 & 3.61 & 4.96 & 2.0 & 3.48 \\
\hline
\end{tabular}

ND: Recommended density of 53,333 plants/ha with one plant per hill at $25 \mathrm{~cm} \times 75 \mathrm{~cm}$ spacing; DD: Double plant population density of 106,666 plants/ha with two plants per hill at $25 \mathrm{~cm} \times 75 \mathrm{~cm}$ spacing.

Total variable cost ( $)$ of various agronomic practices in the production of maize varieties under the two population densities is presented in Table 2.

Table 2. Total variable cost (\#) of various agronomic practices in the production of maize varieties under the two population densities

\begin{tabular}{lll}
\hline Operations & ND & DD \\
\hline Land preparation (2 ploughing) & 14000 & 14000 \\
Spraying & 7000 & 7000 \\
Chemical (force up 3 litres) & 5100 & 5100 \\
Seed (20 and 25kg respectively@N350/kg & 7000 & 8750 \\
Planting & 7200 & 7200 \\
Spraying of guardforce & 7000 & 7000 \\
3 litres of guardforce & 5400 & 5400 \\
NPK fertilizer @6 and 9 bags respectively @ N7000 each & 42000 & 63000 \\
Application of NPK & 7000 & 10000 \\
Application of urea & 5000 & 7500 \\
Urea @ 2 and 3 bags respectively & 16000 & 24000 \\
3 litres of paraquat & 4800 & 4800 \\
Application of paraquat & 7000 & 7000 \\
Harvesting & 20000 & 20000 \\
Processing & 20000 & 20000 \\
Total cost & 174500 & 210750 \\
\hline
\end{tabular}

A total of 174500 is required for ND while N210750 is required for DD. The result of the economic analysis of four different maize varieties planted under normal plant population density and double population density is presented in Table 3. The partial budget analysis showed a negative return to the investment of $\mathrm{N} 20,904$ on LNTP-Y maize variety under double population density while other varieties were positive. This implies that LNTP-Y variety would not be economically feasible using double density population. Farmers would lose as much $\mathrm{N} 20,904$ if embarked on double density technology using LNTP-Y maize variety. Other varieties gave net benefits of N152,724 (LNTP-W), $\$ 26,706$ (BR9928DMRSR) and N121,242 (BR9943DMRSR) respectively, under double density plant population. The result showed that LNTP-W variety was more profitable under double population density. Hence, this technology could be recommended to farmers for uptake and subsequent practice. The partial budget analysis also showed that under the normal plant population density, the net benefit of LNTP-W maize variety has the highest net benefit of N206,146 followed by BR9943DMRSR variety with a net benefit of N169,894, LNTP-Y (N139,366) and BR9928DMRSR (N70,678) respectively. This shows that the most economically viable maize variety under normal plant population density was LNTPW. Hence, this technology could be introduced to farmers for adoption and subsequent use.

However, there is a need for further analysis in order to make a general conclusion of the economic profitability of these varieties of maize under different plant population densities. Therefore, marginal benefit analysis was employed to examine the return on the marginal level to farmers under different scenarios. The result showed that, on the marginal, comparing the benefits of each maize variety under the two different population densities, LNTP-Y variety gave the highest marginal benefit of N160,270 followed by LNTP-W $(\mathrm{N} 53,422)$ and the least was BR9928DMRSR $(\mathrm{N} 43,882)$ Table 3. This shows that LNTP-Y variety gave the highest marginal benefit but may not necessarily be the best because it was the effect of the net benefit of planting under the normal plant population density that suppresses the deficit under the double population density. Since farmers may not be able to cope with planting at both rates, it is, therefore, economical to drop planting LNTP-Y under double plant population. Furthermore, to justify the best economic benefit returns on investment, Benefit-Cost (BC) ratio was carried out. This would help the researcher and extension service provider to advice farmers to make the best decision on which of the maize varieties and plant population density to adopt. The results of BC showed that for every N1 invested on BR9943DMRSR maize variety under normal plant population density, N97 would be gained. This is followed by LNTP-Y (N80) and BR9928DMRSR (N41) respectively. However, the least is LNTP-W variety with BC ratio of N18 on every N1 investment. This implies that BR9943DMRSR is the best economic profitable maize variety under the normal population density. On the double population density, LNTP-W has the highest returns on investment with N72 returns on every $\mathrm{N} 1$ spent. This is followed by BR9943DMRSR (N58), BR9928DMRSR (N13). However, LNTP-Y maize variety under double population density gave a loss of N10 on every N1 invested. This implies that LNTPY maize variety would not be a technology to recommend to farmers under this condition. 
Table 3. Economic analysis of maize varieties under normal and double population densities.

\begin{tabular}{|c|c|c|c|c|c|}
\hline & & \multicolumn{4}{|l|}{ ND } \\
\hline & & LNTP-W & LNTP-Y & BR9928DMRSR & BR9943DMRSR \\
\hline & \multicolumn{5}{|l|}{ Gross benefit } \\
\hline 1 & Average yield (t/ha) & 3.99 & 3.29 & 2.57 & 3.61 \\
\hline 2 & Adjusted yield & 3.59 & 2.96 & 2.31 & 2.25 \\
\hline 3 & Price (N/ton) & 106000 & 106000 & 106000 & 106000 \\
\hline \multirow[t]{2}{*}{4} & Gross farm gate benefit (GB) & \multirow[t]{2}{*}{380646} & \multirow[t]{2}{*}{313866} & \multirow[t]{2}{*}{245178} & \multirow[t]{2}{*}{344394} \\
\hline & Cost of variable input & & & & \\
\hline 5 & Total cost for ND & \multirow[t]{3}{*}{174500} & \multirow[t]{3}{*}{174500} & \multirow[t]{3}{*}{174500} & \multirow[t]{3}{*}{174500} \\
\hline 6 & Total cost for DD & & & & \\
\hline & Net benefit & & & & \\
\hline 7 & Net benefit & 206146 & 139366 & 70678 & 169894 \\
\hline \multirow[t]{2}{*}{8} & Change in net benefit (MB) & 53422 & 160270 & 43882 & 48652 \\
\hline & Benefit-Cost ratio & 1.18 & 0.80 & 0.41 & 0.97 \\
\hline
\end{tabular}

Table 3. Continued.

\begin{tabular}{|c|c|c|c|c|c|}
\hline & & \multicolumn{4}{|l|}{ DD } \\
\hline & & LNTP-W & LNTP-Y & BR9928DMRSR & BR9943DMRSR \\
\hline & Gross benefit & & & & \\
\hline 1 & Average yield (t/ha) & 3.81 & 1.99 & 2.49 & 3.48 \\
\hline 2 & Adjusted yield & 3.43 & 1.79 & 2.24 & 3.13 \\
\hline 3 & Price (N/ton) & 106000 & 106000 & 106000 & 106000 \\
\hline 4 & $\begin{array}{l}\text { Gross farm gate benefit (GB) } \\
\text { Cost of variable input }\end{array}$ & 363474 & 189846 & 237546 & 331992 \\
\hline 5 & Total cost for ND & & & & \\
\hline 6 & $\begin{array}{l}\text { Total cost for DD } \\
\text { Net benefit }\end{array}$ & 210750 & 210750 & 210750 & 210750 \\
\hline 7 & Net benefit & 152724 & -20904 & 26706 & 121242 \\
\hline 8 & Change in net benefit (MB) & & & & \\
\hline & Benefit-Cost ratio & 0.72 & -0.10 & 0.13 & 0.58 \\
\hline
\end{tabular}

Source: Field data, 2019. Note- GB=Gross benefit, MB=Marginal benefit.

\section{Conclusion}

In summary, BR9943DMRSR maize variety satisfied both the necessary and sufficient conditions for economic benefit feasibility for adoption by farmers under both normal and double plant population densities. Maize variety LNTP-W could also serve as a good variety to be cultivated under the two different plant population densities. Therefore, BR9943DMRSR and LNTP-W maize varieties could be recommended to farmers for cultivation under both plant population densities while LNTP-Y could be considered as another option only in normal population density.

It is therefore, recommended that research institute saddled with the mandate of maize production should mass produce the foundation seeds of these two varieties, with the financial assistance of the government for dissemination by the extension agents to the farmers for adoption and improved maize productivity.

\section{References}

[1] Alimi, T. and V. M. Manyong (2000): Partial budget analysis for on-farm research. IITA Research. Guide 65: 53.

[2] Daigneault, A., Brown, P. and Gawith, D. (2016): Dredging versus hedging: Comparing hard infrastructure to ecosystembased adaptation to flooding. Ecol. Econ. 122: 25-35. http://dx.doi.org/10.1016/j.ecolecon.2015.11.019.
[3] Harpinder, S., Nadia, E. S., Chris, W., Fatemeh, B., Kieran, K., Richard, H. and Daniel, F. (2020): Evaluating the holistic costs and benefits of corn production systems in Minnesota, US. Sci Rep 10, 3922 (2020). https://doi.org/10.1038/s41598020-60826-5.

[4] Olasoji, J. O. and O. A. Egbetokun (2017): Assessment of Farmers' Saved Seed and Improved Seed on Maize Productivity in South-Western Nigeria. Journal of Experimental Agriculture International, 18 (3): 1-7 DOI: $10.9734 / \mathrm{JEAI} / 2017 / 34437$.

[5] Melese, K., W. Mohammed and G. Hadgu (2018): On-farm partial budget analysis of pepper (Capsicum Annuum L.) to the application of NP fertilizer and farmyard manure in Raya Azebo District, Northern Ethiopia. African Journal of Agricultural Research, 10 (4): 127-134, DOI: 10.5897/JDAE2017.0858.

[6] Dhakal, S. C., Regmi, P. P., Thapa, R. B., Sah, S. K. and Khatri-Chhetri, D. B. (2015): Productivity and profitability of maize-pumpkin mix cropping in Chitwan, Nepal. Journal of Maize Research and Development 1 (1): 112-122.

[7] Aderibigbe, S. G., Sakariyawo, O. S. and Kasali, A. O. (2017): Performance of maize (Zea mays) cultivars as influenced by grade and application rate of organo-mineral fertilizer in a transitory rain forest. Agrosearch 17 (2): 78-98.

[8] Agbaje, G. O., J. O. Saka, A. A. Adegbite and O. O. Adeyeye (2008): Influence of agronomic practices on yield and profitability in kenaf (Hibiscus cannabinus L.) fibre cultivation. African Journal of Biotechnology, 7 (5): 565-574. 
[9] Asumadu, H., P. Y. Sallah, P. B. Boa-Amponsem, J. Allou and O. B. Manu-Aduening (2004): On-farm evaluation and promotion of quality protein maize hybrids in Ghana. In: African Crop Science Proceedings, 4: 358-364.

[10] Egbetokun O. A., Ajijola S., Awolola, O. A. and Awoyemi, D. O. (2018): Economic Evaluation of Maize Intercropped with Some Major Food Crops in South Western Nigeria. Journal of Cercetari Agronomice LI (176): 27-35.

[11] Olukosi, J. O., S. U. Isitor and M. O. Ode (2006): Introduction to agricultural marketing and prices: principle and application. American Journal of Agriculture and Forestry, 2 (4): 199-205.

[12] Standards Australia (2014): What is a Net Benefit? Available on https: //www.standards.org.au/StandardsDevelopment. Accessed $15^{\text {th }}$ August 2019.
[13] Novacek, M. J. (2011): Twin-Row Production and Optimal Plant Population for Modern Maize Hybrids. MSc Thesis. Agronomy and Horticulture. University of Nebraska Lincoln.

[14] Shelton, A. C. and Tracy, W. F. (2013): Genetic variation and phenotypic response of 15 Sweet Corn (Zea mays L.) hybrids to population density. Sustainability. 5, 2442-2456. DOI: $10.3390 /$ su5062442.

[15] Kondombo, C. P., Tamini, M., Barro, A. and Chantereau, J. (2017): Plant population density effects on agromorphological traits and the yield of grain sorghum varieties in rainfed conditions in Burkina Faso. Agricultural Science Research Journal. 7 (6), 221-229. 